\title{
Strategi komunikasi antaretnik penutur sunda di Kabupaten Pangandaran di tengah kondisi multilingual
}

\author{
Duddy Zein ${ }^{1}$, Nani Darmayanti ${ }^{2}$ \\ ${ }^{1,2}$ Universitas Padjadjaran, Bandung, Indonesia
}

\begin{abstract}
ABSTRAK
Komunikasi antaretnik di Kabupaten Pangandaran memperlihatkan gejala yang menarik, baik dari aspek komunikasi maupun dari aspek lainnya. Hal ini disebabkan oleh kondisi masyarakat di Kabupaten Pangandaran yang multietnik, khususnya Sunda dan Jawa. Kondisi multietnik tersebut menyebabkan kondisi bahasa di Kabupaten Pangandaran menjadi multilingual. Penelitian ini mengkaji strategi komunikasi antaretnik penutur Sunda di Kabupaten Pangandaran di tengah kondisi multilingual. Penelitian ini menggunakan metode kombinasi atau metode gabungan. Penelitian ini dibagi ke dalam tiga tahapan, yaitu tahap penyediaan data, tahap analisis data, dan tahap penyajian hasil analisis data. Metode analisis yang digunakan dalam penelitian ini adalah metode kualitatif. Penelitian ini dilakukan di Kabupaten Pangandaran dengan memilih lima kecamatan sebagai daerah pengamatan yang ditentukan berdasarkan arah mata angin, yaitu Kecamatan Cimerak, Kecamatan Sidamulih, Kecamatan Kalipucang, Kecamatan Padaherang, dan Kecamatan Pangandaran. Masing-masing kecamatan ditentukan empat desa yang dipilih berdasarkan arah mata angin juga. Sebanyak 30 orang yang terdiri dari berbagai kalangan yang tersebar di beberapa kecamatan di Kabupaten Pangandaran dijadikan sebagai informan. Hasil penelitian menunjukkan bahwa: (1) bahasa Sunda sebagai alat komunikasi masih sering digunakan secara konsisten oleh penutur Sunda di Kabupaten Pangandaran, pada tiga ranah komunikasi, yaitu ranah kekeluargaan, kekariban, dan ketetanggaan, (2) strategi komunikasi antaretnik masyarakat tutur Sunda di Kabupaten Pangandaran didominasi oleh alih kode dan campur kode.
\end{abstract}

Kata-kata Kunci: antaretnik; bahasa Sunda; Pangandaran; multilingual; strategi komunikasi

\section{The interethnic communication strategies of Sundanese speakers in Pangandaran amidst multilingual conditions}

\begin{abstract}
Interethnic communication in Pangandaran Regency shows interesting symptoms, both from the aspect of communication and from other aspects. This is caused by the condition of the people in Pangandaran Regency which is multi-ethnic, especially Sundanese and Javanese. This multi-ethnic condition causes the language conditions in Pangandaran District to be multilingual. This study aims to explain the communication strategies of Sundanese speakers in Pangandaran Regency amidst multilingual conditions. This research uses a mixed method. This research was divided into three stages: data supply stage, data analysis stage, and the stage of presenting the results of data analysis. The analytical method used in this study is a qualitative method. This research was conducted in Pangandaran Regency by selecting five districts as the observation area, namely Cimerak, Sidamulih, Kalipucang, Padaherang, and Pangandaran. In each district four villages were chosen based on the direction of the compass. 30 people consisting of various groups scattered in several sub-districts in Pangandaran Regency were assigned as respondents. The results showed that: (1) Sundanese as a communication tool is still often used consistently by Sundanese speakers in Pangandaran Regency, in the three domains of communication, namely the realm of family, intimacy, and neighborhood, (2) the inter-ethnic communication strategy of the Sundanese speaker in Pangandaran Regency is dominated by code switching and code mixing.
\end{abstract}

Keywords: interethnic; Sundanese; Pangandaran; multilingual; communication strategies

Korespondensi: Duddy Zein, M.Si. Universitas Padjadjaran. Jl. Raya Bandung Sumedang KM.21, Kec. Jatinangor Jawa Barat 45363. No. HP/Whatsapp: 081809259808, Email: zein@unpad.ac.id

Submitted: September 2019, Accepted: October 2019, Published: October 2019

ISSN: 2548-3242 (printed), ISSN: 2549-0079 (online). Website: http://jurnal.unpad.ac.id/manajemen-komunikasi 


\section{PENDAHULUAN}

Bahasa merupakan bagian integral dari budaya suatu masyarakat (Fauziah, 2015). Oleh sebab itu, anasir budaya seperti aturan, kebiasaan, dan cara hidup suatu kelompok tutur dapat diejawantahkan dan diekspresikan melalui medium bahasa. Sistem kultural yang dimiliki oleh suatu masyarakat dicerminkan dalam bahasanya, sehingga menciptakan beragam gaya bahasa yang menjadi ciri penanda masyarakat tuturnya. Keberagaman bahasa ini pada masanya nanti dapat memengaruhi komunikasinya, terutama komunikasi interpersonal (antarorang) yang berlatar budaya dan bahasa yang berlainan (Venus, Syafirah, \& Salam, 2019). Secara praktis, fenomena ini dapat menimbulkan kesulitan dan hambatan dalam proses komunikasi pada umumnya.

Dalam proses komunikasi, selain faktor-faktor linguistik, terdapat pula faktorfaktor nonlinguistik yang menjadi faktor penentu penggunaan bahasa sebagai medium komunikasi pada suatu masyarakat tutur tertentu. Faktor-faktor nonlinguistik yang dimaksudkan tersebut adalah faktor sosial dan faktor situasional (Sari \& Medaswari, 2014). Faktor-faktor sosial, kultural, dan situasi serta kondisi tuturan menjadi faktor penyebab munculnya sebuah fenomena variasi bahasa. Hal tersebut disebabkan oleh adanya situasi dan kondisi yang menjadikan suatu bahasa tidak dapat dilepaskan dari faktor sosial dan kultural masyarakat penuturnya tersebut.

Komunikasi antaretnik atau disebut juga komunikasi antarbudaya dapat dipahami sebagai suatu relasi dan hubungan antara individuindividu yang berlainan budaya, misalnya antara suku bangsa, etnik, ras, bahasa, dan sosial (Regar, Kawung, \& Tangkudung, 2014). Komunikasi yang berlangsung pada dasarnya bersifat lisan, sehingga ide yang disampaikan lebih langsung dan nyata (lebih memiliki sense of communication). Pada jenis dan tipe komunikasi ini, kerja sama antarpartisan bersifat lebih nyata, interaktif, resiprokal, dan proses komunikasi yang berlangsung lebih variatif, khususnya yang berhubungan dengan prinsip kerja sama, kesantunan, solidaritas, dan negosiasi makna (semantis).

Secara praktis, pada komunikasi antaretnik terdapat norma-norma dan kaidah-kaidah yang mesti dipatuhi bersama oleh para partisan tuturan (Yohana, 2015). Norma dan kaidah tersebut merupakan sesuatu yang dihargai bersama, sehingga tiap-tiap anggota tutur dari masyarakat tersebut merasa terikat oleh norma dan kaidah tersebut. Proses komunikasi yang dilakukan oleh setiap anggota masyarakat tutur tersebut akan senantiasa terikat oleh norma dan kaidah yang dimaksudkan itu. Itulah sebabnya, dalam proses komunikasi, para partisan akan 
senantiasa menjaga dan menghargai normanorma dan kaidah-kaidah yang dimaksudkan itu. Kondisi ini kadang kala berpengaruh juga terhadap berhasil dan tidaknya proses komunikasi.

Realita tersebut telah mempertegas bahwa masyarakat dan bahasa merupakan dua hal yang tidak dapat dipisahkan. Hermalita (2013) menyatakan bahwa antara masyarakat dan bahasa memiliki relasi dan hubungan timbal balik (resiprokal). Dalam kondisi tertentu, bahasa dapat memengaruhi dan membentuk perilaku dan sikap masyarakat, terutama dalam aspek pola pikir, persepsi, cara pandang, dan cara bergaul. Pandangan tersebut kerap dikenal dengan teori deterministik terhadap bahasa. Begitu juga sebaliknya, pada kondisi dan sitausi konteks tertentu, masyarakat (dalam hal ini pola pikir, persepsi, cara pandang, dan cara bergaulnya) dapat memengaruhi aspek bahasa. Pandangan ini kerap disebut dengan teori instrumentalistik terhadap bahasa (Chaer, 2009).

Bahasa dapat mencerminkan masyarakat dan masyarakat dapat tercermin dalam praktik berbahasa (Hidayat, 2014), begitulah hipotesis yang selama ini diadopsi. Norma, kaidah, dan nilai yang ada pada suatu masyarakat tutur terwujud dan ter ejawantahkan dalam bahasa, melalui pilihan-pilihan kata (diksi), ungkapan, ujaran, sistem makna, penamaan, aspek pragmatis, semantik, dan sebagainya.

Dalam konteks relasi dan hubungan antara bahasa (lingual) dan budaya (kultural), komunikasi antaretnik pada masyarakat bilingual dan/atau multilingual merupakan satu fenomena yang menarik untuk terus dikaji dan diteliti. Pada masyarakat tutur yang bilingual dan/atau multilingual serta multietnik, telah berkumpul beragam etnik dengan beragam budayanya pula. Semua anasir tersebut menyatu dalam satu wadah masyarakat tutur yang diikat oleh kaidah lingual dan kultural yang disepakati bersama. Dalam kondisi demikian, terdapat beragam bahasa dan budaya yang dibawa oleh setiap masyarakat tutur. Keberagaman tersebut pada masanya nanti akan berpengaruh terhadap ekspresi verbal, loyalitas berbahasa, dan sikap bahasanya, ketika anggota tutur melakukan aktivitas komunikasi dengan etnik lainnya. Kesemua tersebut apabila berjalan secara harmoni akan membawa pada keseimbangan kehidupan sosial (Mirawati \& Karimah, 2019).

Fenomena, gejala, dan kondisi demikian terjadi pula pada bahasa Sunda yang ada di Kabupaten Pangandaran. Bahasa Sunda Kabupaten Pangandaran (selanjutnya disebut bahasa Sunda dialek Pangandaran) telah mengalami kontak bahasa dengan bahasabahasa lainnya, khususnya bahasa Indonesia dan bahasa Jawa. Bahasa-bahasa tersebut saling berpengaruh satu sama lain, sehingga dapat 
ditemukan glos-glos dan anasir bahasa lainnya yang memiliki realisasi yang sama dan etimon yang sama pula. Fenomena, gejala, dan kondisi tersebut pada masanya nanti akan memunculkan dan menyebabkan kesimpangsiuran tentang status bahasa di wilayah tersebut. Kesimpangsiuran dan ketidakjelasan status tersebut akan terlihat jelas apabila dilakukan kalkulasi dialektometri (dalam kajian dialektologi bahasa) untuk menentukan status bahasa dan dialek di wilayah tersebut.

Kabupaten Pangandaran merupakan salah satu wilayah yang ada di Provinsi Jawa Barat. Kabupaten Pangandaran memiliki tingkat kompleksitas penduduknya yang cukup tinggi. Kompleksitastersebut, salahsatunya,disebabkan oleh letak geografis secara administratif dari Kabupaten Pangandaran yang berbatasan langsung dengan Kabupaten Cilacap Provinsi Jawa Tengah. Kondisi geografis tersebut telah menjadikan Kabupaten Pangandaran sebagai salah satu daerah enclave (kantung) bahasa yang di dalamnya sangat dimungkinkan adanya persinggungan dan interaksi dua bahasa atau lebih (Pemerintahan Kabupaten Pangandaran., 2017). Persinggungan antarbahasa pada masanya nanti akan memunculkan dinamika lingual yang kompleks pula.

Secara demografis, kabupaten Pangandaran mayoritas berpenduduk suku Sunda. Namun demikian, karena satu dari sekian banyak kebijakan politik pada masa orde baru, yakni transmigrasi dan pemerataan penduduk di wilayah Indonesia, khususnya Jawa, menjadikan banyaknya penduduk suku non-Sunda, dalam hal ini khususnya suku Jawa, yang juga tinggal dan menetap di Kabupaten Pangandaran. Transmigrasi ini juga sedikit-banyaknya akan berpengaruh terhadap dinamika sosiokultural dan lingual yang ada di Pangandaran (Wagiati, Damayanti, \& Zein, 2018).

Kabupaten Pangandaran, secara usia, merupakan satu di antara kabupaten yang masih relatif baru. Kabupaten Pangandaran merupakan wilayah pecahan dari Kabupaten Ciamis, Provinsi Jawa Barat. Kabupaten Pangandaran memiliki potensi pariwisata yang cukup bagus, salah satunya adalah pantai dan laut. Potensi ala mini menjadi modal yang cukup menjanjikan bagi Kabupaten Pangandaran untuk memisahkan diri secara administratif dengan Kabupaten Ciamis. Secara legal-formal, Kabupaten Pangandaran lahir didasarkan pada Undang-Undang Nomor 21 Tahun 2012 tentang Pembentukan Daerah Otonom Baru Kabupaten Pangandaran di Provinsi Jawa Barat.

Dilihat dari status kebahasaannya, Bahasa Sunda dan bahasa Jawa merupakan dua bahasa yang berkerabat, yaitu masuk rumpun Austronesia atau Nusantara (Mahsun, 2015). Bahasa kerabat itu sendiri data dipahami sebagai serumpun bahasa yang diturunkan 
dari sumber yang sama, baik dari aspek kata, etimon, dan sebagainya. Relasi dan hubungan di antara bahasa sekerabat ternyata tidak sama dekatnya antara satu bahasa dengan bahasa yang lainnya; ada yang lebih dekat atau lebih jauh. Wacana (2013) telah mengelompokkan bahasa sekerabat berdasarkan jauh dekatnya relasi dan hubungan yang dinamakan dengan istilah subgrouping. Telah banyak penelitian tentang subgrouping bahasa Nusantara (Fox, 2019; Mahsun, 2010; Wacana, 2013). Mahsun (2010) secara spesifik, telah mengelompokkan bahasa Sunda dan bahasa Jawa sebagai dua bahasa yang berkerabat. Kedua bahasa tersebut memiliki relasi dan hubungan yang cukup dekat.

Hal yang lebih pelik perihal kondisi bahasa daerahsebagai satudiantarakekayaanintelektual yang mesti dijaga dan dilestarikan adalah apabila pembahasan dibawa ke arah politik bahasa dalam hal ini nasionalisasi bahasa Indonesia. Kebijakan politik bahasa, dalam hal ini berupa penetapan bahasa Indonesia sebagai bahasa nasional, sedikit-banyaknya telah menjadi satu hal yang patut disyukuri. Sebagai bahasa nasional, bahasa Indonesia telah menempatkan dirinya sebagai salah satu alat komunikasi dan interaksi antarsuku bangsa yang hidup di negara Indonesia (Wagiati \& Zein, 2018). Perbedaan sosiokultural dan lingual tidak lagi menjadi penghalang komunikasi antaretnik. Dengan ditetapkannya bahasa Indonesia sebagai bahasa nasional, komunikasi antarsuku bangsa akan sangat mudah untuk dilakukan.

Di lain sisi, kebijakan politik bahasa, berupa penetapan bahasa Indonesia sebagai bahasa nasional pun ternyata masih memunculkan dilema dan problem lainnya. Di satu sisi, kebijakan tersebut bernilai positif karena telah mampu mengurangi potensi disintegrasi antarbangsa di Indonesia. Namun di sisi yang lain, adanya politik bahasa yang menempatkan bahasa Indonesia sebagai bahasa nasional, sedikit-banyaknya juga akan memengaruhi penggunaan bahasa-bahasa daerah (Wagiati \& Zein, 2018). Itulah sebabnya, dewasa ini, keberadaan bahasa-bahasa daerah mulai mengalami tekanan fungsional, seiring dengan politik bahasa tersebut. Atas fakta tersebut di atas, dewasa ini dapat disaksikan bersama bahwa beberapa bahasa daerah sudah mulai ditinggalkan oleh penuturnya, meskipun mereka sama-sama berkomunikasi dengan penutur daerah yang sama. Dengan demikian, disadari ataupun tidak, bahasa-bahasa daerah telah mengalami pergeseran bahasa - atau bahkan mengarah kepada kepunahan bahasa. Jika kondisi ini terus dibiarkan, tidak menutup kemungkinan akan mengarah kepada gejala kepunahan bahasa (language death) (Wagiati \& Zein, 2018).

Pada komunikasi antaretnik, selain terikat oleh kaidah lingual, setiap anggota 
masyarakat tutur juga terikat oleh norma budaya masyarakatnya. Efektivitas komunikasi antaretnik, dapat dihubungkan dengan sejumlah variabel atau komponen komunikasi, yaitu ideologi interpersonal; situasi dan kondisi; hubungan dan relasi antara penutur dan mitra tutur; latar belakang partisan tuturan, latar belakang terjadinya tuturan; tujuan tuturan, dan tingkat keamanan wajah/muka si penutur ataupun mitra tutur (Muslim, 2017). Variabelvariabel tersebut memiliki korelasi yang cukup erat dengan pilihan-pilihan bahasa yang diambil oleh setiap anggota partisan tutur yang ada pada komunikasi antaretnik tersebut. Strategi pilihan-pilihan bahasa ini bersifat mutual, dalam arti bahwa siapa pun yang diajak bicara, pilihan bahasanya menjadi suatu tuntutan berdasarkan kaidah sosial, psikologis, dan kultural.

Pada praktiknya, penggunaan bahasa pada komunikasi antaretnik kerap kali cenderung memanfaatkan pola-pola tertentu, seperti kecenderungan yang bersifat langsung (straight-forward) dan mempertimbangkan serta melihat konteks dan sitausi tuturan. Konteks yang dimaksud adalah konteks sosial, yakni berupa siapa mitra tutur (partisipan), di mana tuturan tersebut diutarakan, bagaimana perasaan penutur, bagaimana latar sosial yang ada, dan bagaimana fungsi interaksi pada saat komunikasi antara penutur dan mitra tutur, kesantunan yang digunakan, dan berbagai relasi sosial lainnya yang muncul pada saat komunikasi antaretnik berlangsung.

Praktik komunikasi, baik komunikasi interpersonal maupun komunikasi antaretnik, pada hakikat dan realitasnya, tidak dapat dipisahkan dari faktor sosiokultural masyarakat penuturnya. Kondisi ini pada masanya nanti akan mengakibatkan praktik dan ekspresi suatu bahasa sangat dipengaruhi oleh praktik sosiokultural suatu masyarakat penuturnya tersebut. Hal ini senada dengan apa yang diungkapkan oleh Pastika bahwa bahasa memiliki fungsi dan peran yang amat dominan dalam kehidupan manusia, karena bahasa tidak hanya menjadi bagian integral dari kebudayaan yang tak dapat dipisahkan, tetapi juga dapat menjadi titik penentu perkembangan dan kemajuan budaya itu sendiri (Pastika, 2005). Kondisi semacam ini semakin meyakinkan kita bahwa antara bahasa dan konteks sosiokultural penuturnya memiliki relasi dan hubungan yang sangat erat dan tidak dapat dipisahkan. Oleh sebab itu, praktik berbahasa sangat dipengaruhi oleh latar belakang sosiokultural masyarakat bahasa tersebut. Setiap latar belakang sosiokultural dapat menciptakan pola dan jenis komunikasi tersendiri yang membedakannya dengan komunikasi yang lainnya. Para penutur yang latar belakangnya berasal dari bahasa yang mengenal undak usuk, misalnya, tentu akan menciptakan relasi dan komunikasi bahasa 
yang memperhatikan aturan dan norma tersebut.

Begitu pula sebaliknya. Pada kondisi demikian, terkadang latar belakang sosiokultural ini, apabila tidak disikapi dengan bijak, akan menjadi faktor penyebab terjadinya kesalahan komunikasi (Mas'udah, 2014)

Selain faktor-faktor linguistik, ada juga faktor-faktor nonlinguistik yang memengaruhi pemakaian bahasa sebagai alat komunikasi pada suatu kelompok tutur tertentu. Faktor nonlinguistik yang dimaksud adalah faktor sosial dan faktor situasional (Sari \& Medaswari, 2014). Faktor-faktor sosial, budaya, dan situasi serta kondisi tuturan menyebabkan munculnya sebuah fenomena variasi bahasa. Hal ini disebabkan oleh adanya kondisi yang membuat suatu bahasa tidak bisa dilepaskan dari faktor sosial dan budaya masyarakat penuturnya.

Penggunaan bahasa pada suatu masyarakat tutur - termasuk bahasa Sunda - sebagai alat komunikasi tidaklah bersifat monolitik; melainkan sangat bervariatif (Wagiati \& Zein, 2018). Kondisi ini menyebabkan munculnya realitas lingual yang menyatakan bahwa dalam suatu masyarakat tutur tertentu tidaklah ada penutur yang hanya monolingual. Biasanya, penutur suatu bahasa memiliki kompetensi penguasaan dua atau lebih bahasa yang pada masanya nanti kondisi ini akan mengakibatkan adanya kontak dan interaksi antarbahasa. Dalam situasi konteks tuturan, kontak bahasa sangat memungkinkan terjadi pada saat penutur suatu bahasa sedang mempelajari bahasa keduanya. Realitas lainnya adalah adanya suatu kondisi berupa bilingualisme, yang dalam hal ini dua bahasa atau lebih digunakan bersamaan oleh penutur dalam satu situasi konteks tuturan.

Dalam komunikasi sehari-hari, pada beberapa situasi kondisi, bahasa Sunda sedikit demi sedikit sudah mulai ditinggalkan oleh sebagian penuturnya, meskipun mereka berkomunikasi dengan sesama penutur Sunda (Wagiati \& Zein, 2018). Adanya pandangan yang menyatakan bahwa bahasa Indonesia dianggap sebagai bahasa yang memiliki kedudukan yang lebih tinggi dan prestise daripada bahasa daerah, menjadi salah satu faktor penyebab mengapa bahasa Sunda sedikit demi sedikit mulai ditinggalkan oleh penuturnya. Meskipun demikian, penggunaan bahasa Sunda tidak secara keseluruhan mulai ditinggalkan. Masih ada sekelompok penutur yang tetap menjaga dan melestarikan penggunaan bahasa Sunda sebagai alat komunikasinya, khususnya dalam beberapa konteks tuturan tertentu. Pada kenyataannya, mereka pun mampu menguasai bahasa Indonesia, tetapi karena satu dan lain hal, mereka lebih memilih untuk menggunakan bahasa Sunda sebagai bahasa komunikasinya, daripada menggunakan bahasa Indonesia. Itu artinya, konteks tuturan dan interlokutor sangat berpengaruh terhadap pemilihan bahasa oleh 
dwibahasawan yang pada masanya nanti akan berpengaruh pula terhadap pemertahanan dan pergeseran bahasa (Darmawanti, 2013).

Senada dengan fenomena lingual yang telah disampaikan di atas, tulisan ini berupaya untuk memerikan perihal komunikasi antaretnik pada masyarakat tutur Sunda di Kabupaten Pangandaran. Secarakhusus, tulisaninibertujuan memberikan hal ikhwal komunikasi antaretnik penutur Sunda di Kabupaten Pangandaran dan faktor-faktor yang memengaruhi pilihan bahasa penutur Sunda di Kabupaten Pangandaran.

Kajian ini dilakukan di Kabupaten Pangandaran dengan memilih lima kecamatan sebagai daerah pengamatan yang ditentukan berdasarkan arah mata angin. Masing-masing kecamatan ditentukan empat desa yang dipilih berdasarkan arah mata angin juga. Daerahdaerah yang diambil sebagai tempat penelitian adalah Kecamatan Cimerak (Desa Legok Jawa, Desa Kertaharja, Desa Masawah, dan Desa Sindangsari); Kecamatan Padaherang (Desa Wuluh, Desa Paledah, Desa Maruyungsari, dan Desa Sindangwangi); Kecamatan Kalipucang (Desa Tunggilis, Desa Bagolo, Desa Cibuluh, dan Desa Emplak); Kecamatan Sidamulih (Desa Cikembulan, Desa Pajaten, Desa Sidamulih, dan Desa Sukaresik); dan Kecamatan Pangandaran (Desa Wonoharjo, Desa Sidomulyo, Desa Sukaharjo, dan Desa Pananjung).

\section{METODE PENELITIAN}

Fokus kajian pada penelitian ini adalah tentang strategi komunikasi antaretnik. Pendekatan yang digunakan dalam penelitian ini terdiri atas dua pendekatan, yaitu pendekatan secara teoretis dan pendekatan secara metodologis. Secara teoretis, pendekatan yang dipakai di dalam penelitian ini adalah pendekatan komunikasi. Adapun secara metodologis, pendekatan yang dipakai di dalam penelitian ini adalah pendekatan kombinasi (metode penelitian gabungan). Metode kombinasi itu sendiri dapat dipahami sebagai pendekatan penelitian yang menggabungkan dan menghubungkan antara metode penelitian kualitatif dan kuantitatif (Cresswell, 2009). Sementera itu, pendekatan deskriptif meletakkan dasarnya pada serangkaian fakta, yang secara empiris diperoleh dari penuturpenuturnya, sehingga hasilnya berupa perian seperti apa adanya; tidak ditambah dan tidak dikurangi. Penggunaan metode deskriptif ini senada dengan apa yang dijelaskan Sudaryanto (2015) bahwa data yang didapatkan dalam penelitian deskriptif adalah hasil pengamatan penulis tanpa menilai salah atau benar suatu data.

Penelitian ini dibagi ke dalam tiga tahapan, yaitu tahap penyediaan data, tahap analisis data, dan tahap penyajian hasil 
analisis data. Pelaksanaan penelitian diawali dengan penyediaan data yang dilakukan dengan beberapa teknik berikut ini: (1) teknik partisipasi atau peran serta, (20 teknik observasi atau pengamatan, (3) teknik wawancara, dan (4) teknik rekonstruksi data intuitif dan introspeksi. Pada tahap penyediaan data, langkah pertama yang diambil adalah menentukan dan menetapkan daerah yang akan dijadikan sebagai lokasi dilaksanakannya penelitian ini.

Tahap analisis data dilakukan dengan menggunakan metode kualitatif; artinya bahwa serangkaian kegiatan analisis yang dilakukan pada penelitian ini berkaitan dan berhubungan langsung dengan pola-pola yang umum pada wujud dan perilaku data yang ada yang dipengaruhi dan yang hadir bersama dengan konteks-konteksnya (Kholil, 2016). Penganalisisan data juga dilakukan dengan langkah-langkah berikut: (1) penelaahan dan penyeleksian data, (2) pengidentifikasian dan pengunitan data, (3) pengategorisasian atau penggolongan data, dan (4) penafsiran dan penjelasan makna data.

Data yang sudah dianalisis disajikan secara deskriptif, yaitu perumusan dan pengungkapan hasil analisis dengan menggunakan kata-kata atau kalimat-kalimat.

Penelitian ini dilakukan di Kabupaten Pangandaran dengan memilih lima kecamatan sebagai daerah pengamatan yang ditentukan berdasarkan arah mata angin. Masing-masing kecamatan ditentukan empat desa yang dipilih berdasarkan arah mata angin juga. Daerahdaerah yang diambil sebagai tempat penelitian adalah Kecamatan Cimerak (Desa Legok Jawa, Desa Kertaharja, Desa Masawah, dan Desa Sindangsari); Kecamatan Padaherang (Desa Wuluh, Desa Paledah, Desa Maruyungsari, dan Desa Sindangwangi); Kecamatan Kalipucang (Desa Tunggilis, Desa Bagolo, Desa Cibuluh, dan Desa Emplak); Kecamatan Sidamulih (Desa Cikembulan, Desa Pajaten, Desa Sidamulih, dan Desa Sukaresik); dan Kecamatan Pangandaran (Desa Wonoharjo, Desa Sidomulyo, Desa Sukaharjo, dan Desa Pananjung).

Penelitian ini dilakukan dengan menggunakan instrumen penelitian yang sudah disiapkan. Pada instrumen penelitian ini, peneliti mencoba menguak fakta-fakta tentang komunikasi antaretnik yang ada di Kabupaten Pangandaran, khususnya berkenaan dengan penggunaan dan pilihan-pilihan bahasa oleh masyarakat di wilayah tersebut.

Sebanyak 30 orang yang terdiri dari berbagai kalangan pada tiga jenjang usia (remaja, dewasa, dan orang tua) yang beragam telah ditetapkan sebagai responden penelitian ini. Setiap responden diminta untuk menjawab pertanyaan-pertanyaan seputar penggunaan bahasa dan pilihan-pilihan bahasa pada enam ranah komunikasi dengan beberapa jenis 
komunikasi, yaitu penggunaan bahasa dengan kakek/nenek di rumah; penggunaan bahasa dengan kakek/nenek di pusat keramaian; penggunaan bahasa dengan kakek/nenek di kantor kelurahan/kecamatan; penggunaan bahasa dengan bapak/ibu di rumah; penggunaan bahasa dengan bapak/ibu di pusat keramaian; penggunaan bahasa dengan bapak/ibu di kantor kelurahan/kecamatan; penggunaan bahasa dengan saudara kandung di rumah; penggunaan bahasa dengan saudara kandung di pusat keramaian; penggunaan bahasa dengan saudara kandung di kantor kelurahan/kecamatan; penggunaan bahasa dengan teman dekat di rt/rw yang sama; penggunaan bahasa dengan tetangga (tua); tetangga (muda); penggunaan bahasa dengan tetangga (sebaya); tetangga (anakanak); penggunaan bahasa dengan tukang ojeg yang dikenal baik; penggunaan bahasa dengan tukang ojeg yang tidak dikenal; penggunaan bahasa dengan penjaga toko yang dikenal baik; penggunaan bahasa dengan penjaga toko yang tidak dikenal baik; penggunaan bahasa dengan pedagang di pasar tradisional; penggunaan bahasa dengan guru di kantor sekolah; penggunaan bahasa dengan guru di luar kantor sekolah; penggunaan bahasa dengan pegawai kelurahan/kecamatan di kantor; penggunaan bahasa dengan pegawai kelurahan/kecamatan di luar kantor; orang yang tidak dikenal.

\section{HASIL DAN PEMBAHASAN}

Kabupaten Pangandaran merupakan satu di antara kabupaten yang ada di wilayah Provinsi Jawa Barat. Lahirnya Kabupaten Pangandaran dilatarbelakangi oleh Undang-Undang Nomor 21 tahun 2012 sebagai legal-formal lahirnya kabupaten baru (DOB) yang ditandatangani oleh Presiden Susilo Bambang Yudhoyono pada tanggal 16 November 2012. Keberadaan Kabupaten Pangandaran dipertegas dengan adanya peraturan Menteri Hukum dan HAM pada waktu itu, yaitu Amir Syamsudin, pada tanggal 17 November 2012. Kedua produk hukum tersebut menjadi landasan utama kelahiran Kabupaten Pangandaran sebagai kabupaten baru di Jawa Barat. Sebelumnya, Pangandaran merupakan salah satu wilayah bagian administratif dari Kabupaten Ciamis.

Undang-Undang Nomor 21 tahun 2012 menyebutkan bahwa daerah administratif Kabupaten Pangandaran sebelumnya merupakan sebagian wilayah Kabupaten Ciamis, yang terdiri atas: Kecamatan Parigi, Kecamatan Cijulang, Kecamatan Cimerak, Kecamatan Cigugur, Kecamatan Langkaplancar, Kecamatan Mangunjata, Kecamatan Padaherang, Kecamatan Kalipucang, Kecamatan Pangandaran, dan Kecamatan Sidamulih. Dari sederetan kecamatan tersebut, ditetapkanlah Kecamatan Parigi sebagai ibu 
kota Kabupaten Pangandaran.

Kabupaten Pangandaran memiliki luas wilayah 168.509 Ha dengan luas laut 67.340 Ha. Kabupaten Pangandaran memiliki pantai sepanjang $91 \mathrm{Km}$ (Pemerintahan Kabupaten Pangandaran., 2017).

Bidang pariwisata merupakan bagian potensi unggulan dari Kabupaten Pangandaran. Kabupaten Pangandaran sangat terkenal dengan potensi pariwisata di bidang pantai dan sungai. Beberapa di antara potensi pariwisata Kabupaten Pangandaran tersebut adalah: Pantai Pangandaran, taman wisata alam (cagar alam Pananjung), Pantai Batu Hiu, Pantai Batu Karas, Pantai Madasari, Pantai Karapyak, Cukang Taneuh (green canyon), Citumang, dan Santirah.

Potensi lainnya yang menjadi fokus pengembangan dari Kabupaten Pangandaran adalah bidang pertanian. Sebelum memisahkan diri menjadi kabupaten tersendiri, luas wilayah pertanian yang ada di Kabupaten Ciamis tercatat sekitar 51.903 (data pada tahun 2012) dan sekitar 26 persen dari keseluruhannya berada di wilayah administratif Pangandaran sekarang. Itu artinya, potensi pertanian Kabupaten Pangandaran sangat relatif memadai untuk pengembangan bidang pertanian, khususnya pangan. Pertanian tanaman padi merupakan satu di antara komoditas unggulan yang menjadi fokus pengembangan di bidang pertanian di Kabupaten Pangandaran. Selain padi, subsektor palawija juga menjadi primadona bidang pertanian yang sedang dikembangkan di Kabupaten Pangandaran. Adapun sektor lainnya adalah jagung, kacang tanah, ubi kayu, ubi jalar, kacang hijau, dan lainnya.

Ditinjau dari sudut pandang demografis, Kabupaten Pangandaran bisa dikategorikan sebagai wilayah multietnik, khususnya Sunda dan Jawa. Jika ditarik jauh ke belakang dalam konteks historis, perpaduan antar etnis Sunda dan Jawa di Pangandaran (Jawa Barat - Indonesia) memiliki jejak historis yang amat panjang. Dahulu, kerajaan Sunda lahir dan berkembang di wilayah Jawa Barat, dan mengalami perkembangan pesat sekitar tahun 669-1579 M. Pusat kejayaan kerajaan ini terjadi ketika sultan Kerajaa Mataram di bawah pimpinan Sultan Agung Kusumo Hanyokro (1613-145). Pada saat itu, hampir seluruh wilayah Jawa Tengah dan sebagian wilayah Jawa Timur berada di bawah kepemimpinannya. Dalam konteks lokalitas Pangandaran, ternyata dengan dikuasainya sebagian besar wilayah Jawa Tengah dan Jawa Timur tidak otomatis terjadinya migrasi orang Jawa ke wilayah Jawa Barat, dalam hal ini Pangandaran. Belum ada penelitian yang dapat memberikan gambaran tentang migrasi etnis Jawa ke Pangandaran terjadi sebelum abad XX.

Gambaran migrasi etnis Jawa ke 
Pangandaran (Jawa Barat - Indonesia) malah muncul pada naskah folklor yang berkembang pada etnis Jawa di Pangandaran. Dalam folklor tersebut disebutkan bahwa terdapat seorang etnis Jawa yang dianggap orang sakti yang memiliki jasa membuka daerah Pangandaran yang pada waktu itu masih berupa hutan belantara, Namanya Mbah Bungkus. Dalam folklor tersebut dikisahkan Bipati Sukapura pada saat itu meminta bantuan masyarakat untuk membuka hutan di daerah tersebut yang akan dijadikan sebagai wilayah layak huni. Namun, tidak ada yang sanggup memenuhi permintaan bupati tersebut. Hingga akhirnya bupati-bupati di wilayah Jawa meminta bantuan kepada Mbah Bungkus. Dengan kesaktiannya, Mbah Bungkus berhasil membuka daerah Cikembulan - cikalbakal wilayah Pangandaran. Secara etimologis, cikembulan berasal dari kata kembulan yang artinya menyatu atau berkumpul. Itu artinya, Cikembulan dianggap sebagai daerah persatuan atau perkumpulan antara etnis Jawa dan etnis Sunda, dan mereka hidup berdampingan.

Menurut folklor tersebut, nama Pangandaran lahir dari orang Sunda yang pada saat itu sedang membawakan makanan untuk orang-orang Jawa yang sedang bertani dan berladang. Makanan disebut oleh orang Jawa dengan kata pangan dan orang Sunda menyebutnya dengan kata daharan. Gabungan dari kedua kata tersebut akhirnya melahirkan kata pangandaharan yang kemudian berupan menjadi Pangandaran (Samino, Wawancara 21 April 2019).

Secara historis, kelahiran Pangandaran memang memiliki kompleksitas kultural. Adanya hubungan yang erat antara etnis Sunda dan etnis Jawa menjadikan Pangandaran sebagai salah satu wilayah multietnik, multikultur, dan multilingual. Atas dasar itu, maka wajar apabila kondisi kebahasaan di daerah Pangandaran begitu kompleks.

Dari segi geografis, Pangandaran dianggap sebagai wilayah yang memiliki daya tarik alam, kesuburan tanah, ketersediaan lapangan pekerjaan, dan kondisi kultural masyarakat yang terbuka dengan keberadaan etnis lain telah menjadi daya tarik masyarakat dari luar daerah untuk bermigrasi ke Pangandaran (Jawa Barat - Indonesia). Faktor geografis inilah yang menurut informan kami, Samino (generasi kedua imigran asal Jawa), menjadi salah satu faktor pemicu adanya perpindahan etnis Jawa ke Pangandaran. Faktor geografis ini tidak bisa dilepaskan dari faktor demografis, ke berlimpahan kekayaan alam Pangandaran telah menyebabkan adanya lonjakan migrasi penduduk etnis Jawa ke daerah Pangandaran. Migrasi etnis Jawa ini membawa pengaruh kultural, termasuk pengaruh bahasa Jawa terhadap bahasa Sunda dialek Pangandaran.

Selain itu, berbicara tentang Kabupaten 
Pangandaran, tidak bisa dilepaskan juga dari pembahasan tentang politik transmigrasi pada masa orde baru. Berbicara tentang transmigrasi di Indonesia, tentu sangat erat hubungannya dengan sosok presiden RI ke-2, yakni Soeharto. Pada masa orde baru, transmigrasi menjadi salah satu program andalan Soeharto yang tertuang dalam Pembangunan Lima Tahun (Pelita) 1 sampai 6. Program transmigrasi era Soeharto masuk dalam generasi transmigrasi orde baru. Sebelumnya, pada tahun 1905 s.d. 1942 dikenal dengan istilah konolisasi. Kemudian Jepang masuk menjajah Indonesia, kemudian istilahnya berubah menjadi kerja rodi (romusha). Pasca kemerdekaan hingga 1966, pada masa orde lama, barulah ada transmigrasi, tetapi keberlangsungannya tidak berjalan mulus.

Ketika Soeharto menjadi presiden RI, Pelita I sampai VI dicanangkan pada 1969, dan pada saat itulah transmigrasi mulai digencarkan.

Program transmigrasi di era Soeharto ini sering dikenal dengan istilah bedol desa atau sejuta gambut. Kebijakan politik ini sedikitbanyaknya berdampak terhadap kehidupan sosio-kultural di tengah-tengah masyarakat Indonesia. Banyak lahan-lahan kosong yang digarap oleh para imigran dan kemudian lahanlahan tersebut, seiring perkembangan zaman dan generasi, berubah menjadi wilayah-wilayah layak huni mulai dari tingkat kampung, desa, hingga kabupaten.
Kabupaten Pangandaran (Jawa Barat Indonesia) - yang sebelumnya masuk ke dalam wilayah administratif Kabupaten Ciamis -- juga tidak lepas dari kebijakan politik Soeharto. Di wilayah ini, pada masa itu, masih banyak lahan kosong yang mesti digarap. Hingga akhirnya banyak pula masyarakat dari etnis Jawa yang berpindah ke sebagian wilayah Pangandaran dan menetap hingga masa generasi sekarang. Kebijakan politik ini juga berdampak pada dinamika sosio-kultural yang ada di Pangandaran, khususnya pada aspek lingual di wilayah tersebut.

Selanjutnya, bagian ini membahas sikap verbalmasyarakattutur Sunda dalam komunikasi antaretnik di Kabupaten Pangandaran. Kajian ini tidak bisa dilepaskan dari sikap berbahasa dan pilihan bahasa yang diambil oleh penutur di setiap ranah komunikasinya. Analisis dibagi menjadi dua bagian, yaitu(1) penggunaan bahasa Sunda pada enam ranah komunikasi, yaitu ranah kekeluargaan, ketetanggaan, kekariban, pendidikan, transaksi, dan pemerintahan dan (2) faktor-faktor yang memengaruhi pilihan bahasa penutur Sunda di Kabupaten Pangandaran.

Sebanyak 30 orang yang terdiri dari berbagai kalangan dalam tiga jenjang usia - mulai dari remaja, dewasa, dan orang tua (usia 10 s.d. 60 tahun) -- yang tersebar di beberapa kecamatan di Kabupaten Pangandaran dijadikan sebagai responden. Semua responden diminta menjawab 
kuesioner yang berisi pertanyaan tentang situasi percakapan dan bahasa yang digunakan oleh mereka untuk menjaring pengakuan responden. Responden diminta menjawab bahasa apa yang dipakai dalam situasi-situasi tadi. Bahasa atau tipe bahasa yang disajikan untuk dipilih adalah bahasa Sunda, bahasa Indonesia, dan bahasa lainnya, dalam hal ini adalah bahasa Jawa. Untuk setiap bahasa pada setiap ranah percakapan, ditentukan intensitas penggunaannya dengan penilaian berbentuk skala intensitas, yaitu selalu, kadang-kadang, dan tidak pernah. Masing-masing skala yang ada diberi nilai 20 (sering), 10 (kadang-kadang), dan 0 (tidak pernah). Bahasa Sunda dijadikan acuan untuk penilaian intensitasnya. Semakin sering bahasa Sunda digunakan sebagai alat komunikasi pada setiap ranah komunikasi, maka sikap dan pemertahanan bahasa Sunda pada ranah tersebut semakin bagus, begitu pun sebaliknya.

Dari sejumlah responden yang sudah diteliti, sebagian besar dari mereka memilih menggunakan bahasa Sunda sebagai bahasa komunikasi pada ranah-ranah komunikasi. Dari enamranah komunikasi yang ada, pada tiga ranah komunikasi, yaitu kekeluargaan, kekariban, dan ketetanggaan, para responden lebih memilih menggunakan bahasa Sunda sebagai bahasa komunikasinya. Adapun pada ranah transaksi, pendidikan, dan pemerintahan, sebagian besar dari responden lebih menggunakan bahasa non-
Sunda sebagai bahasa komunikasinya, dalam hal ini antara bahasa Indonesia dan bahasa Jawa. Berikut adalah diagram yang menunjukkan pemilihan bahasa Sunda dalam enam ranah komunikasi.

Tabel 1 Penggunaan Bahasa Sunda di Kabupaten Pangandaran

\begin{tabular}{clc}
\hline No. & Ranah Komunikasi & Rerata \\
\hline 1 & Kekeluargaan & 13,85 \\
2 & Kekariban & 15,33 \\
3 & Ketetanggaan & 15,50 \\
4 & Transaksi & 5,20 \\
5 & Pendidikan & 3,67 \\
6 & Pemerintahan & 6,89 \\
\hline
\end{tabular}

Sumber: hasil penelitian, 2019

Pada tabel 1 dapat dilihat skor pemilihan bahasa Sunda di Kabupaten Pangandaran pada enam ranah komunikasi. Skor didapatkan dari pengisian pilihan penggunaan bahasa Sunda di Kabupaten Pangandaran - skor (20) untuk selalu, (10) kadang-kadang, dan (0) tidak pernah. Pada beberapa ranah komunikasi, seperti transaksi, pendidikan, dan pemerintahan, responden lebih sering menggunakan bahasa Indonesia dan/atau bahasa Jawa sebagai bahasa komunikasinya. Bahasa Sunda pada ranah transaksi, pendidikan, dan pemerintahan jarang digunakan, bahkan lebih mendekati skor tidak pernah, yakni skor 5,20 untuk ranah transaksi, skor 3,67 untuk ranah pendidikan, dan 6,89 untuk ranah pemerintahan. Adapun pada ranah 
kekeluargaan, kekariban, dan ketetanggaan, bahasa Sunda masih sering digunakan. Skor yang didapat pada empat ranah tersebut memperlihatkan bahwa bahasa Sunda hampir selalu digunakan, yaitu skor 13,85 untuk ranah kekeluargaan, 15,33 untuk ranah kekariban, dan 15,50 untuk ranah ketetanggaan.

Strategi komunikasi antaretnik masyarakat tutur Sunda di Kabupaten Pangandaran didominasi oleh alih kode dan campur kode. Hal ini dapat dilihat dari fenomena pilihan bahasa yang digunakan untuk komunikasi antaretnik masyarakat tutur di setiap ranah komunikasi (kekeluargaan, kekariban, ketetanggaan, transaksi, pendidikan, dan pemerintahan).

Alih kode (code switching) merupakan suatu peristiwa perubahan dan peralihan dari satu kode kepada kode yang lain dalam satu situasi tuturan tertentu. Sebagai contoh, seseorang yang menggunakan bahasa daerah kemudian beralih menggunakan bahasa Indonesia, atau sebaliknya. Gejala alih kode dalam konteks sosiolinguistik menjadi bahasan dalam aspek ketergantungan bahasa (language dependency) dalam masyarakat multilingual yang masingmasing bahasa masih cenderung mendukung fungsi masing-masing dan masing-masing fungi sesuai dengan konteksnya. Suandi, (2014) mendefinisikan alih kode sebagai satu istilah yang digunakan untuk menyatakan pergantian (peralihan) pemakaian dua bahasa atau lebih, atau beberapa variasi dari satu bahasa atau beberapa ragam dari satu gaya. Pendapat ini senada dengan apa yang diungkapkan Hermalita (2013) yang menyatakan bahwa alih kode sebagai penggantian peralihan pemakaian bahasa atau ragam fungsiolek ke dalam ragam yang lain.

Rohmani, Amir, \& Anindyarani, (2013) menjelaskan alih kode dan campur kode. Bila dalam suatu peristiwa tutur terjadi peralihan dari satu klausa suatu bahasa ke klausa bahasa lain, maka peristiwa yang terjadi adalah alih kode. Tetapi, apabila di dalam suatu peristiwa tutur, klausa-klausa maupun frase-frase yang digunakan terdiri dari klausa dan frase campuran (hybrid clauses, hybrid phrases), dan masing-masing klausa atau frase itu tidak lagi mendukung fungsi sendiri-sendiri, maka peristiwa yang terjadi adalah campur kode bukan alih kode.

Alih kode berhubungan erat dengan lingkungan situasional sebagai ciri eksternalnya, juga berkaitan dengan penutur dan bahasa yang digunakan sebagai ciri internalnya. Suandi (2014: 133) mengungkapkan ada beberapa ciri dari alih kode, diantaranya adalah: (1) alih kode terjadi karena adanya kontak bahasa dan saling ketergantungan bahasa (language dependeny); (2) alih kode akan mungkin terjadi jika masyarakat atau peserta penuturnya adalah orang-orang yang bilingual atau multilingual 
dan atau diglosik; (3) di dalam alih kode pemakaian bahasa atau kode masih mendukung fungsinya sendiri-sendiri sesuai dengan konteks yang dipendamnya; (4) fungsi tiap-tiap bahasa atau kode disesuaikan dengan situasi yang terkait dengan perubahan isi pembicaraan; dan (5) alih kode terjadi disebabkan oleh tuntutan yang berlatar belakang tertentu, baik yang ada pada diri penutur pertama, orang kedua, maupun situasi yang mewadahi terjadinya pembicaraan.

Tuturan yang kita lakukan tidak lepas dari apa yang diungkapkan Fishman (Simatupang, Rohmadi, \& Saddhono, 2018) yang berkaitan erat dengan siapa berbicara, dengan bahasa apa, kepada siapa, kapan, dan dengan tujuan apa. Berdasarkan aspek tersebut, penutur melakukan alih kode dan campur kode dipengaruhi oleh faktor (1) penutur, (2) mitra tutur, (3) perubahan situasi dengan hadirnya orang ketiga, (4) perubahan dari formal ke informal, (5) perubahan topik pembicaraan, (6) topik/ pokok pembicaraan.

Strategi komunikasi antaretnik masyarakat tutur Sunda pada ranah kekeluargaan, pilihan penggunaan bahasa selain bahasa Sunda adalah bahasa Jawa dan bahasa Indonesia. Faktor yang sangat berpengaruh terhadap pilihan bahasa pada ranah kekeluargaan adalah faktor pernikahan. Di Kabupaten Pangandaran, telah banyak terjadi pernikahan lintas etnis, khususnya antara etnis Sunda dengan etnis Jawa. Kondisi multietnik pada ranah kekeluargaan inilah yang menjadi sebab penentu pilihan-pilihan bahasa dan penggunaan bahasa antar anggota keluarga.

Situasi percakapan yang terjadi pada ranah kekeluargaan adalah situasi percakapan yang mencakup lawan bicara dan konteks percakapan, yaitu (1) percakapan dengan kakek/ nenek di rumah, (2) percakapan dengan kakek/ nenek di pusat keramaian, (3) percakapan dengan kakek/nenek di kantor kelurahan/ kecamatan, (4) percakapan dengan bapak/ibu di rumah, (5) percakapan dengan bapak/ibu di pusat keramaian, (6) percakapan dengan bapak/ibu di kantor kelurahan/kecamatan, (7) percakapan dengan saudara kandung di rumah, (8) percakapan dengan saudara kandung di pusat keramaian, dan (9) percakapan dengan saudara kandung di kantor kelurahan/kecamatan.

Strategi komunikasi antar etnik masyarakat tutur Sunda pada ranah kekariban, intensitas penggunaan bahasa Sunda masih terbilang tinggi. Penggunaan bahasa pada ranah kekariban ini dilihat dari situasi percakapan dengan teman dekat di RT/RW yang sama. Lebih seringnya bahasa Sunda digunakan pada ranah kekariban karena kondisi dan situasi percakapan pada ranah ini memiliki tingkat keintiman yang juga tinggi. Biasanya orang akan lebih nyaman jika berbicara dengan bahasa yang sama-sama dipahami dan dimengerti.

Pada ranah ketetanggaan, bahasa Sunda 
juga masih sering digunakan sebagai bahasa komunikasinya. Penggunaan bahasa pada ranah ketetanggan ini terbagi ke dalam empat situasi komunikasi dengan mempertimbangkan lawan bicara dan situasinya, yaitu percakapan dengan tetangga (tua), tetangga (muda), tetangga (sebaya), dan tetangga (anak-anak).

Pada ranah transaksi masyarakat berbahasa Sunda di Kabupaten Pangandaran jarang memilih menggunakan bahasa Sunda sebagai bahasa komunikasinya. Pemilihan bahasa ini dilihat dari hasil skor yang didapat dari intensitas penggunaan bahasa Sunda, bahasa Jawa, dan bahasa Indonesia pada ranah tersebut. Masyarakat di Kabupaten Pangandaran lebih sering menggunakan bahasa selain Sunda jika berkomunikasi dengan penjaga toko dan tukang ojek dalam berbagai situasi komunikasi. Pemilihan bahasa pada ranah transaksi ini terbagi ke dalam lima situasi komunikasi dengan mempertimbangkan lawan bicara dan situasinya, yaitu percakapan dengan tukang ojeg yang dikenal baik, percakapan dengan tukang ojek yang tidak dikenal, percakapan dengan penjaga toko yang dikenal baik, percakapan dengan penjaga toko yang tidak dikenal, dan percakapan dengan pedagang di pasar tradisional.

Pada ranah pendidikan, masyarakat tutur Sunda di Kabupaten Pangandaran lebih memilih menggunakan bahasa Indonesia sebagai bahasa komunikasinya. Pemilihan bahasa ini dilihat dari hasil skor yang didapat dari intensitas penggunaan bahasa Sunda, bahasa Jawa, dan bahasa Indonesia pada ranah tersebut. Masyarakat di Kabupaten Pangandaran lebih sering menggunakan bahasa Indonesia jika berkomunikasi dengan guru, baik di kantor maupun di luar kantor sekolah, dalam berbagai situasi komunikasi. Pemilihan bahasa pada ranah pendidikan ini terbagi ke dalam dua situasi komunikasi dengan mempertimbangkan lawan bicara dan situasinya, yaitu percakapan dengan guru di kantor sekolah dan percakapn dengan guru di luar kantor sekolah.

Pada ranah pemerintahan, masyarakat tutur Sunda di Kabupaten Pangandaran juga jarang menggunakan bahasa Sunda. Pemilihan bahasa ini dilihat dari hasil skor yang didapat dari intensitas penggunaan bahasa Sunda, bahasa Jawa, dan bahasa Indonesia pada ranah tersebut. Masyarakat di Kabupaten Pangandaran lebih sering menggunakan bahasa Indonesia dibandingkan bahasa Sunda dalam berbagai situasi komunikasi. Pemilihan bahasa pada ranah pemerintahan ini terbagi ke dalam tiga situasi komunikasi dengan mempertimbangkan lawan bicara dan situasinya, yaitu percakapan dengan pegawai kelurahan/kecamatan di kantor, percakapan dengan pegawai kelurahan/ kecamatan di luar kantor, dan percakapan dengan orang yang tidak dikenal. 
Jika dilihat dari penggunaan bahasa Sunda di Kabupaten Pangandaran pada jenjang usia yang bervariatif, mulai dari remaja, dewasa, dan orang tua, pada enam ranah komunikasi, terlihat dengan jelas bahwa pada beberapa ranah komunikasi, bahasa Sunda masih dipertahankan dengan baik, yaitu pada ranah kekeluargaan, kekariban, dan ketetanggaan. Sementara itu, pada ranah transaksi, pendidikan, dan pemerintahan, bahasa Sunda sudah mulai tergantikan oleh bahasa Indonesia dan/atau bahasa Jawa sebagai bahasa komunikasinya.

Ada beberapa faktor yang memengaruhi kondisi tersebut. Faktor-faktor tersebut adalah sebagai berikut.

Semakin tingginya mobilitas masyarakat Sunda yang hidup dan menetap di luar wilayah kebahasaannya dan semakin banyaknya kawin-campur antara orang Sunda dan nonSunda. Generasi selanjutnya dari keluarga yang mengalami kawin-campur hampir bisa dipastikan akan memperoleh bahasa Indonesia sebagai bahasa pertama. Kecenderungan ini kecenderungan memperoleh bahasa Indonesiatidak hanya terjadi di derah perkotaan, tetapi juga sudah mulai merambah ke daerah pedesaan. Faktor demografis ini ditambah dengan semakin gencarnya mobilitas masyarakat luar etnis Sunda yang tinggal dan menatap di wilayah Sunda. Kondisi ini, di satu sisi, memang memberikan dampak positif, salah satunya adalah berkenaan dengan perkembangan pola pikir suatu masyarakat yang semakin meluas. Artinya, dengan adanya interaksi antaretnik, akan terjadi pula saling tukar pandangan dan pemikiran. Dengan demikian, akan berdampak pula pada perkembangan pola pikir suatu masyarakat. Namun demikian, di sisi yang lain, kondsi ini juga menjadi tantangan dan ancaman bagi bahasa etnis tertentu apabila gencarnya komunikasi antaretnik tidak dibarengi dengan peningkatan sikap berbahasa dan loyalitas berbahasanya.

Faktor lainnya adalah semakin banyaknya penutur non-Sunda yang menetap di wilayah Sunda, baik untuk tinggal sementara maupun untuk menetap dalam waktu yang lama. Semakin kompleksnya fenomena sosial yang ada di suatu wilayah menyebabkan penggunaan bahasa yang semakin kompleks pula. Kondisi ini telah menyebabkan banyaknya dwibahasawan dan multibahasawan di suatu wilayah tutur. Multibahasawan, di satu sisi, memberikan dampak positif bagi orang yang bersangkutan. Multibahasawan akan mudah memahami dan mencerna informasi yang datang dari sumber yang bukan bahasa ibu dan bahasa nasionalnya. Karena bagaimanapun juga, bahasa merupakan alat untuk memahami dan menyerap informasi. Dengan bahasa, informasi akan mudah dipahami. Namun demikian, kondisi multibahasawan juga akan menjadi faktor penentu yang memengaruhi 
pergeseran suatu bahasa. Multibahasawan akan sering menampilkan gejala campur kode dan alih kode secara berkesinambungan, yang pada masanya nanti gejala lingual ini akan berdampak pula pada pergeseran suatu bahasa.

Pangandaran dianggap sebagai wilayah yang memiliki daya tarik alam, kesuburan tanah, ketersediaan lapangan pekerjaan, dan kondisi kultural masyarakat yang terbuka dengan keberadaan etnis lain telah menjadi daya tarik masyarakat dari luar daerah untuk bermigrasi ke Pangandaran. Faktor geografis ini tidak bisa dilepaskan dari faktor demografis, keberlimpahan kekayaan alam Pangandaran telah menyebabkan adanya lonjakan migrasi penduduk etnis Jawa ke daerah Pangandaran. Migrasi etnis Jawa ini membawa pengaruh kultural, termasuk pengaruh bahasa Jawa terhadap bahasa Sunda dialek Pangandaran.

Diberlakukannya sistem pemerintahan lokal dan regional yang merupakan kepanjangan dari sistem birokrasi pemerintahan di tingkat nasional, dengan sendirinya telah menyebabkan pergeseran bahasa, khususnya pada ranah-ranah tertentu. Masyarakat Sunda memandang bahwa bahasa Indonesia (ragam baku dan non baku) memiliki tingkat prestise yang lebih tinggi jika dibandingkan dengan bahasa daerah yang ada. Pandangan ini, mau tidak mau, telah menjadikan bahasa daerah terpinggirkan pemakaiannya, khususnya di dalam situasi formal, seperti pada ranah pendidikan dan ranah pemerintahan.

Bahasa Indonesia dianggap memiliki prestise yang tinggi dan dijadikan tujuan utama penguasaan bahasa. Hal ini berkaitan erat dengan faktor ekonomi dan masa depan, seperti pekerjaan, kesuksesan bisnis, karier, dan sebagainya dalam kehidupan yang semakin modern. Persepsi seperti ini sangat berpengaruh terhadap tingkat loyalitas bahasa. Rendahnya kebanggaan mereka terhadap bahasanya sendiri menjadi problematik tersendiri dalam kaitannya dengan pemertahanan dan revitalisasi bahasa Sunda di Kabupaten Pangandaran.

\section{SIMPULAN}

Bahasa Sunda sebagai alat komunikasi masih sering digunakan secara konsisten oleh penutur Sunda di Kabupaten Pangandaran, pada tiga ranah komunikasi, yaitu ranah kekeluargaan, kekariban, dan ketetanggaan. Hal ini berarti bahwa pemertahanan bahasa Sunda pada ketiga ranah tersebut masih relatif kuat. Sementara itu, komunikasi pada ranah transaksi, pendidikan, dan pemerintahan, bahasa Sunda sudah mengalami pergeseran dan sudah mulai tergantikan oleh bahasa non-Sunda, dalam hal ini bahasa Indonesia dan bahasa Jawa, sebagai bahasa komunikasinya. Hal ini berarti bahwa pada ketiga ranah tersebut, pemertahanan bahasa Sunda sudah mulai melemah.

Strategi komunikasi antaretnik masyarakat 
tutur Sunda di Kabupaten Pangandaran didominasi oleh alih kode dan campur kode. Hal ini dapat dilihat dari fenomena pilihan bahasa yang digunakan untuk komunikasi antaretnik masyarakat tutur di setiap ranah komunikasi (kekeluargaan, kekariban, ketetanggaan, transaksi, pendidikan, dan pemerintahan). Campur kode dan alih kode menjadi strategi komunikasi penutur Sunda di Kabupaten Pangandaran yang digunakan secara bergantian dalam setiap konteks tutur yang terjadi.

Ada beberapa faktor yang memengaruhi kondisi kebahasaan di Kabupaten Pangandaran. Semakin tingginya mobilitas masyarakat Sunda yang hidup dan menetap di luar wilayah kebahasaannya dan semakin banyaknya kawincampur antara orang Sunda dan non-Sunda. Kemudian, semakin banyaknya penutur nonSunda yang menetap di wilayah Sunda, baik untuk tinggal sementara maupun untuk menetap dalam waktu yang lama. Hal ini juga menjadi salah satu faktor yang tidak dapat dilupakan. Pangandaran dianggap sebagai wilayah yang memiliki daya tarik alam, kesuburan tanah, ketersediaan lapangan pekerjaan, dan kondisi kultural masyarakat yang terbuka dengan keberadaan etnis lain telah menjadi daya tarik masyarakat dari luar daerah untuk bermigrasi ke Pangandaran. Diberlakukannya sistem pemerintahanlokaldan regionalyangmerupakan kepanjangan dari sistem birokrasi pemerintahan di tingkat nasional, dengan sendirinya telah menyebabkan pergeseran bahasa, khususnya pada ranah-ranah tertentu. Bahasa Indonesia dianggap memiliki prestise yang tinggi dan dijadikan tujuan utama penguasaan bahasa. Hal ini berkaitan erat dengan faktor ekonomi dan masa depan, seperti pekerjaan, kesuksesan bisnis, karier, dan sebagainya dalam kehidupan yang semakin modern.

\section{DAFTAR PUSTAKA}

Chaer, A. (2009). Psikolinguistik: kajian teoretik. Jakarta: Rineka Cipta.

Cresswell, Jo. W. (2009). Research design pendekatan penelitian kulitatif, kuantitatif, dan mixed. Yogyakarta: Pustaka Pelajar.

Darmawanti. (2013). Alih kode dalam konteks percakapan guru di MAN 3 Makassar (code switching in teachers conversation in MAN 3 Makassar ). 9(2), 326-341.

Fauziah, S. (2015). Faktor sosiokultural dalam pemakaian bahasa. Zawiyah Jurnal Pemikiran Islam, 1(1), 154-174.

Fox, J. J. (2019). Eastern Indonesia in Austronesian perspective: the evidence of relational terminologies. Archipel: Études Interdisciplinaires Sur Le Monde Insulindien, 90, 118-124.

Hermalita, K. (2013). Analisis sosiolinguistik perubahan bahasa pada masa pra-pasca pubertas. Al-Turats, 19(1).

Hidayat, N. S. (2014). Hubungan berbahasa, berpikir, dan berbudaya. Sosial Budaya: Media Komunikasi Ilmu-Ilmu Sosial Dan Budaya, 11(2).

Kholil, S. (2016). Metodologi penelitian komunikasi. Medan: Perdana Publishing. 
Mahsun. (2010). Genolinguistik: kolaborasi linguistik dengan genetika dalam pengelompokan bahasa dan populasi penuturnya. Yogyakarta: Pustaka Pelajar.

Mahsun. (2015). Indonesia dalam perspektif politik kebahasaan. Jakarta: Raja Grafindo. Mas'udah, D. (2014). Mindfulness dalam komunikasi antarbudaya (studi deskriptif pada peserta Indonesia - Poland CrossCultural Program). Profetik, 7(2), 77-89.

Mirawati, I., \& Karimah, K. El. (2019). Chinese harmony communication theory: kompetensi komunikasi untuk keseimbangan hidup. Jurnal Manajemen Komunikasi, 3(1), 97. https://doi. org/10.24198/jmk.v3i1.20655.

Muslim, B. (2017). Penyimpangan teori brown dan levinson dalam tindak tutur peserta talkshow Indonesia lawyers club (ilc) di tv one dan relevansinya terhadap pembelajaran bahasa Indonesia di sma. Retorika: Jurnall Ilmu Bahasa, 3(1), 104-117.

Pastika, I. W. (2005). Linguistik kebudayaan: konsep dan model. Jurnal Linguistika, 12(22), 102-112.

Pemerintahan Kabupaten Pangandaran. (2017). Profil Kabupaten Pangandaran. Retrieved September 7, 2019, from web.pangandaran. go.id/public/profile/profil-kabupatenpangandaran.

Regar, P. P., Kawung, E., \& Tangkudung, J. P. M. (2014). Pola komunikasi antar budaya dan identitas etnik Sangihe - Talaud - Sitaro (Studi pada Masyarakat Etnik SangerTahuna-Sitaro di Kota Manado). Journal Acta Diurna, 3(4), 1-10.

S., R., Amir, F., \& Anindyarani, A. (2013). Analisis alih kode dan campur kode pada novel negeri 5 menara karya Ahmad Fuadi. BASASTRA: Jurnal Penelitian Bahasa,
Sastra Indoneia Dan Pengajarannya, 2(1), $1-16$.

Sari, N. W. E. S., \& Medaswari, I. A. (2014). Pilihan bahasa siswa kelas XI IPA 2 SMA (SLUA) 1 Saraswati Denpasar. Jurnal Bakti Saraswati, 3(2), 40-47.

Simatupang, R. R., Rohmadi, M., \& Saddhono, K. (2018). Tuturan dalam pembelajaran Bahasa Indonesia (kajian sosiolinguistik alih kode dan campur kode). Kajian Linguistik Dan Sastra, 3(2), 119-130.

Suandi, I. N. (2014). Sosiolinguistik. Yogyakarta: Graha Ilmu.

Sudaryanto. (2015). Metode dan teknik analisis bahasa: pengantar penelitian wahana kebudayaan secara linguistis. Yogyakarta: Penerbit Universitas Sanata Dharma.

Venus, A., Syafirah, N. A., \& Salam, N. E. (2019). Stereotip, melayu, etnik, reformasi, pendatang. Jurnal Manajemen Komunikasi, 3(2), 131-141.

Wacana, D. I. P. (2013). Relasi kekerabatan bahasa-bahasa di Kabupaten Poso. Jurnal Kependidikan, 6(1), 1-9.

Wagiati, Damayanti, N., \& Zein, D. (2018). Migration of Javanese language and its influence on sundanese language pangandaran dialect in West Java, Indonesia: A Study in Geolinguistic. International Journal of Humanities Social Sciences and Education, 6(7), 22-33.

Wagiati, \& Zein, D. (2018). Pemertahanan bahasa sunda dalam upacara pernikahan tradisional di Kabupaten Bandung. Jurnal Pendidikan Dan Kebudayaan, 3(2), 186201.

Yohana, N. (2015). Kaidah interaksi komunikasi tradisi lisan basiacuang dalam adat perkawinan Melayu Kampar Riau. Jurnal Penelitian Komunikasi, 18(1), 43-56. 